\title{
Information warfare model based on a cellular automaton *
}

\section{M.E. Stepantsov ${ }^{* *}$}

Keldysh Institute of Applied Mathematics RAS, Moscow, Russian Federation

This paper considers an integro-differential model of informational confrontation based on Rashevky's neurological scheme which is difficult to modify for taking into account the differences in susceptibility of individuals to propaganda, the special influence of the reference group for a given individual or the variance of some characteristics of individuals. This can be done by using a discrete model based on a cellular automaton having macrodynamic similar to that of the continuous model. Such a model is proposed in this paper, its dynamics is studied and it is shown to yield the main results, given by the continuous model.

Keywords: informational confrontation, mathematical modeling, cellular automata, simulation.

Introduction. The problems of information conflicts belong now not to IT field but spread out to politics, economics and security spheres. We may no longer solve them qualitatively, obtaining only some speculative answers, but require precise quantitative results and, therefore, need some mathematical tools to implement such an approach.

The simplest models of information (in the form of rumours) influencing society were proposed as early as 1960s [1]. But some later models based on those did not take into consideration mass media and details of the process by which a person accepts the information such as reference group (see [2], [3]).

Researches based on a new approach [4] consider dependence of accepting the new information on the intensity of propaganda [5] and the impact of mass media [6], but still do not to take into account the differences in susceptibility of individuals to propaganda or the special influence of the reference group for a given individual.

In this paper we consider models of informational confrontation [7], [8] based on Rashevsky's neurological scheme [9].

The simplest case of propaganda was investigated in [7], [10] by using the classical approach. Let individuals choose one of two positions on a certain issue, for example, which of the parties $-\mathrm{L}$ or $\mathrm{R}$ - to support in the elections.

The model proposed in [7] has the form of an integro-differential equation

$$
\frac{d \psi}{d t}=A\left(C\left(2 \int_{-\psi(t)}^{+\infty} N(\varphi) d \varphi-N_{0}\right)+b_{R}-b_{L}\right)-a \psi
$$

with initial value

\footnotetext{
* The work is supported by RFBR, projects 18-01-00619, 18-01-00551 and 19-010-00423.

** E-mail: mews@yandex.ru.
} 


$$
L(0)=\int_{-\infty}^{-\psi(0)} N(\varphi) d \varphi
$$

Here $\psi(t)$ denotes the preference shift of the individuals influenced by propaganda, the numbers of $\mathrm{L}$ and $\mathrm{R}$ supporters being

$$
\begin{aligned}
& L(t)=\int_{-\infty}^{-\psi(t)} N(\varphi) d \varphi \\
& R(t)=\int_{-\psi(t)}^{+\infty} N(\varphi) d \varphi
\end{aligned}
$$

function $N(\varphi)$ defining the distribution of the attitudes of individuals to the alternatives $\mathrm{L}$ and $\mathrm{R}$ and

$$
N_{0}=\int_{-\infty}^{+\infty} N(\varphi) d \varphi
$$

being the population. $b_{R}, b_{L}, C, A$ and $a$ denote the influences of $\mathrm{R}$ and $\mathrm{L}$ propaganda and of the public opinion, the ability of individuals to change their minds and the decrement rate of such changes.

$N(\varphi)$ distribution describes the variation of views on the alternatives. The Gaussian law of this distribution centered at zero corresponds to a consolidated society, and the function equal to the sum of two symmetrical Gaussian distribution functions describes a society polarized on this issue [10].

Although the exact solution to general problem (1), (2) has not been obtained, it can be easily studied [7]. However, the continuous model cannot be modified to solve specific problems. It is difficult to take into account the differences in susceptibility of individuals to propaganda or the special influence of the reference group for a given individual, and the variance of any characteristics of individuals, except for their initial relations to alternatives.

These difficulties can be solved by replacing the continuous model with a cellular automaton with macrodynamics similar to one the integro-differential model. This approach has already been applied to Mikhailov's Power-society model [11]. It is more adequate from the point of methodology, since we are modeling discrete phenomena using discrete mathematical objects with no transition to continuous description.

Model. We will now propose such a cellular automaton that describes the same reality as the original continuous model of informational confrontation and show that it yields the same macrodynamics and results. Expanding its applicability range will be the subject of further research.

Let us take a simple orthogonal lattice for the field of the proposed cellular automaton. Each cell contains a finite automaton that describes the current views of an individual, having three possible states: support for the L alternative (-1), support for the R alternative (1), and undecided (0). We also 
assign to each cell a parameter describing the individual's views without the influence of propaganda that can also have one of the three listed values remaining constant.

When we consider the macrodynamics of this model, the expression similar (but not precisely equal) to $\psi$ is

$$
\psi^{*}=\frac{R(t)-L(t)}{N_{0}}
$$

The derivative of it is given by the expression

$$
\begin{gathered}
\frac{d \psi^{*}}{d t}=\frac{\frac{d R(t)}{d t}-\frac{d L(t)}{d t}}{N_{0}} \\
\frac{d \psi^{*}}{d t}=2 \frac{d \psi}{d t} \frac{N(\psi)}{N_{0}}
\end{gathered}
$$

that can be used verify the similarity between macrodynamics of discrete and continuous models. Still, most of the results in [7] and [10] were obtained in terms of the dynamics of supporters' quantities, so comparison of models can be done with the help of these values.

All the terms in equation (1) except for the integral one can be easily 'translated into the language of a cellular automaton'. As for the integral term, it is simply the difference in the supporters' quantities. We can obtain this value by direct calculation over the field of the cellular automaton and use it with the corresponding coefficient as the equivalent of the integral term.

Thus, each time step in the proposed cellular automaton includes three algorithms given below, which are applied sequentially to each cell of the field.

A algorithm: direct propaganda influence.

if $\Delta>0$ then

if Center $=0$ and $r<\Delta$ then Center $=1$

if Center $=-1$ and $r<\Delta$ then Center $=0$

end if

if $\Delta<0$ then

if Center $=0$ and $r<-\Delta$ then Center $=-1$

if Center $=1$ and $r<-\Delta$ then Center $=0$

end if

Herein $\Delta=A^{*}\left(b_{R}-b_{L}\right)$ is the parameter responsible for the total influence of direct propaganda, $r$ is a random number uniformly distributed over the interval $[0 ; 1]$, Center is the standard designation of the state of the considered cell (in contrast to its neighbors) in the field of a cellular automaton.

Algorithm B: decrement of changes in point of view caused by propaganda.

if not $z=$ Center then

if $r<a^{*}$ then

if Center $>z$ then Center $=$ Center -1

if Center $<z$ then Center $=$ Center +1 
end if

end if

Herein $a^{*}$ is the parameter denoting the decrement rate of the influence of propaganda, $z$ sets the initial state of the cell (the individual's own views on the alternatives) specified for each cell.

Algorithm C: the influence of public opinion.

if $\psi^{*}>0$ then

if Center $<1$ and $r<c^{*} \psi^{*}$ then Center $=$ Center +1

end if

if $\psi^{*}<0$ then

if Center $>-1$ and $r<-c^{*} \psi^{*}$ then Center $=$ Center -1

end if

Herein $\psi^{*}$ is previously introduced value showing the excess of the quantity of the alternative $\mathrm{R}$ supporters over one of L supporters, $c^{*}$ describes the influence of public opinion.

Simulation. The proposed cellular automaton, as shown above, should yield the same macrodynamics as the original continuous model. To verify this statement, a number of computational experiments were carried out. We used field size of 20x20 (containing 400 cells). In each experiment, the initial distribution of opinions was equal to the values of own opinions $z$. The quantity of undecided individuals was set as the normalized value of the continuous distribution function at $\varphi=$ 0 , and the numbers of supporters of two alternatives - as the values of this function at the inflection points for a consolidated society and its values at the maxima for a polarized one. The exact quantities of a priori supporters of each of the alternatives for $\mathrm{N}_{0}=400$ are given in the table below.

\begin{tabular}{|l|c|c|c|}
\hline \multirow{2}{*}{ Society } & \multicolumn{3}{|c|}{ The quantity of } \\
\cline { 2 - 4 } & L supporters & Undecided & R supporters \\
\hline Consolidated & 110 & 180 & 110 \\
\hline Polarized & 150 & 100 & 150 \\
\hline
\end{tabular}

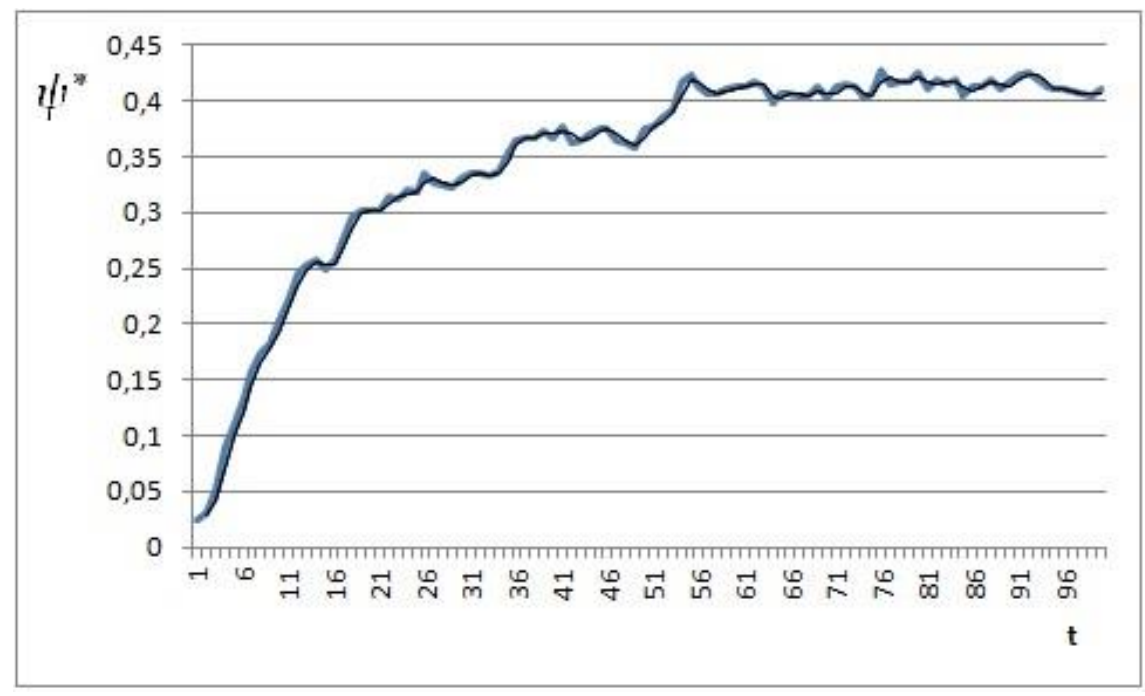

Fig. 1. The formation of stationary values of supporters quantities 
In several hundred of computational experiments we studied the dynamics of $\psi^{*}(t)$ function at various parameter values. In each experiment the function tended to a stationary value, therefore, similarly to [10], stationary values of supporters' quantities for each of the alternatives were formed. A typical example of such a behavior is presented in Fig. 1.

Since similarly to the continuous model, the dynamics of the system reaches a stationary solution, it is possible to investigate the response function to propaganda as in [10]. This function is the dependence of the stationary value of supporters' quantity of one of the alternatives (for example, $\mathrm{R})$ on the intensity of propaganda.

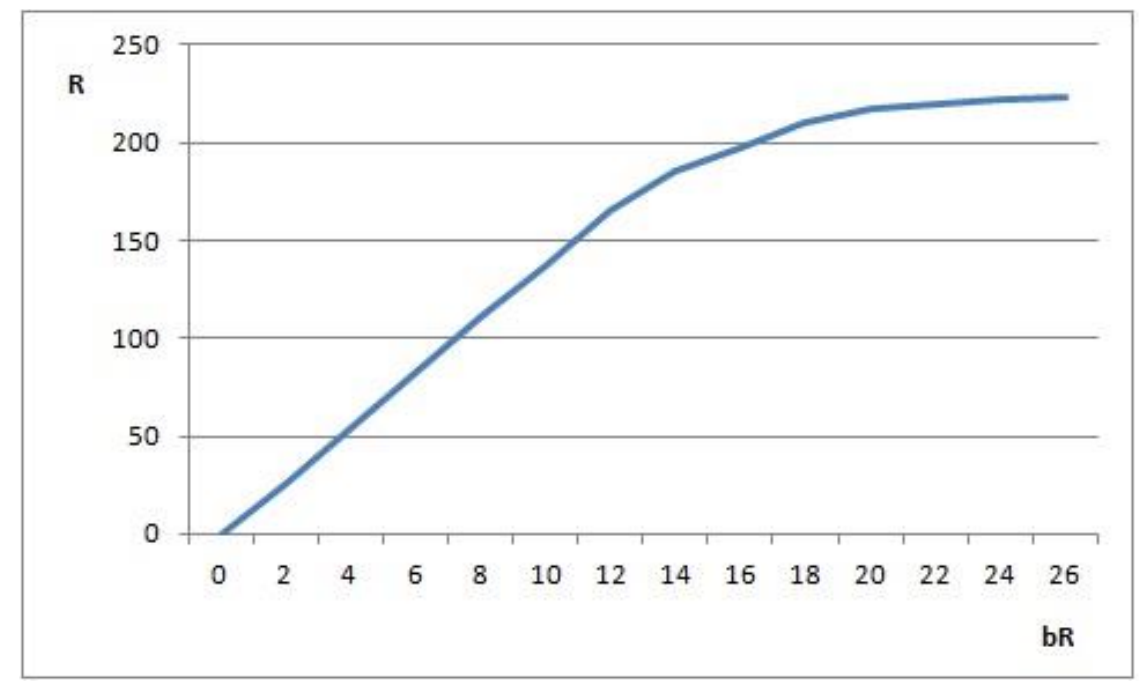

Fig. 2. The response function for a consolidated society

In these experiments we used the following values: $b_{L}=10, c^{*}=0,1, a^{*}=0,1, A^{*}=0,1$. We studied the dependence of the stationary value of $R$ on $b_{\mathrm{R}}$ that varied from 0 to 26 . Similarly to continuous model [10], this dependence turned out to be an upward convex function for a consolidated society (Fig. 2), and an S-shaped function for a polarized society (Fig. 3).

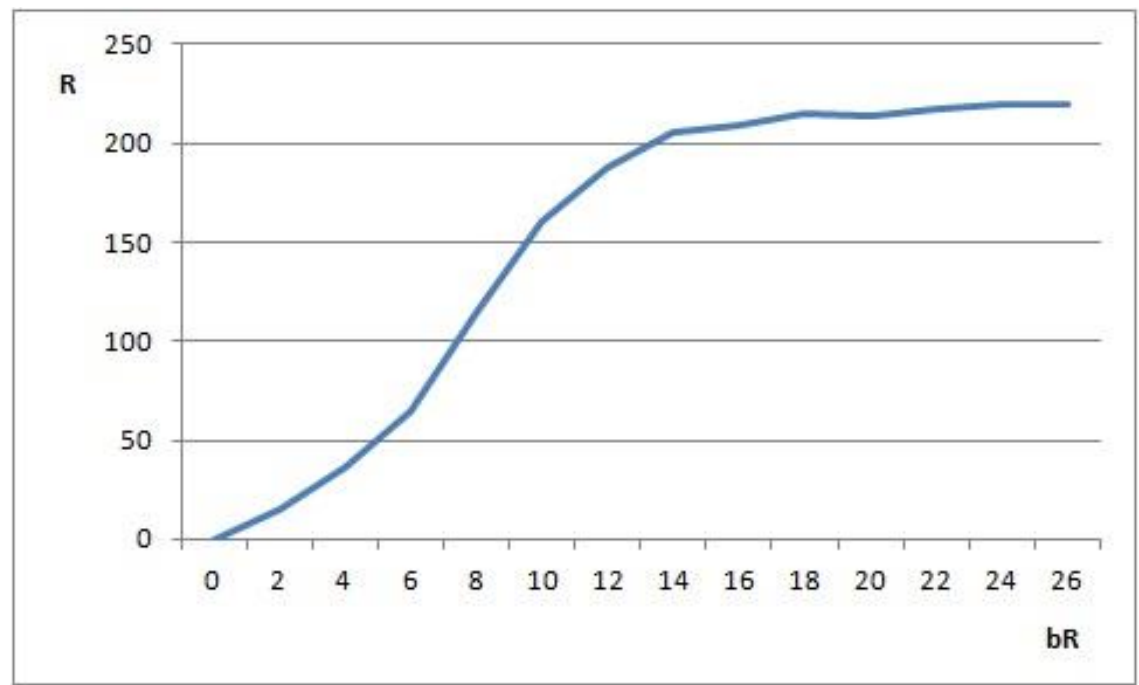

Fig. 3. The response function for a polarized society 
Conclusion. Thus, the discrete cellular automaton model proposed in this paper performs macrodynamics that is similar to one of the original continuous model and allows to obtain results that were observed with the help of the continuous model.

It should be noted that the continuous model does not consider the greatest impact that small groups have on an individual's opinion, taking into account only the influence of society as a whole. The proposed model allows us to take this effect into consideration by using cellular automaton rules of the effect of a cell neighborhood on its state. Furthermore, the initial model does not show the process of internalizing external views by an individual, which can easily be done in the cellular automaton model by setting rules for changing the cell parameter $\mathrm{z}$ that describes the internal belief of an individual. The aspects mentioned may be important for understanding the dynamics of the system under research, that is why it seems appropriate to use a discrete cellular automaton model to study them.

\section{References}

1. D.J. Daley, D.G. Kendall Stochastic rumors // Journal of the Institute of Mathematics and its Applications, vol. 1, pp. 42-55, 1964.

2. Liang'an Huo, Peiqing Huang, Chun-Xiang Guo. Analyzing the Dynamics of a Rumor Transmission Model with Incubation // Discrete Dynamics in Nature and Society, vol. 2012, Article ID 328151, 21 pages, 2012

3. R. Isea, R. Mayo-García Mathematical analysis of the spreading of a rumor among different subgroups of spreaders // Pure and Applied Mathematics Letters, 2015, vol. 2015, p. 50-54.

4. A.A. Samarskii, A.P. Mikhailov Principles of mathematical modelling: Ideas, methods, examples. Taylor \& Francis. 2002.

5. A.P. Mikhailov, N.A. Marevtseva Models of information warfare // Mathematical Models and Computer Simulations, May 2012, Volume 4, Issue 3, pp 251-259

6. A.P. Mikhailov, A.P. Petrov Osnovnye napravleniia matematicheskogo modelirovaniia informatsionnogo protivoborstva v sotsiume // Predstavitelnaia vlast - XXI vek. 2019, N5-6. P. 36-46.

7. Petrov A. P., Maslov A. I., Tsaplin N. A. Modeling Position Selection by Individuals during Information Warfare in Society // Mathematical Models and Computer Simulations, 2016, Vol. 8, No. 4, pp. 401-408, doi:10.1134/S2070048216040141. http://link.springer.com/article/10.1134/S2070048216040141

8. Petrov A.P., Lebedev S.A. Online Political Flashmob: the Case of 632305222316434 // Computational mathematics and information technologies. — 2019. - No 1. - P. 17-28. doi: 10.23947/25878999-2019-1-1-17-28 http://cmit-journal.ru/upload/iblock/dfb/_-2019-1_2.pdf

9. Rashevsky N. Mathematical biophysics: physico-mathematical foundations of biology. - Univ. of Chicago, Chicago Press. -1938

10. Proncheva O., Petrov A. Response function to propaganda in consolidated and polarized societies // Information wars - 2018. - 3 (47). - P. 50-53.

11. Stepantsov M.E. Simulation of the "Power-Society-Economics" System with Elements of Corruption Based on Cellular Automata // Mathematical Models and Computer Simulations, March 2018, Volume 10, Issue 2. P. 249-254. https://link.springer.com/article/10.1134/S2070048218020126

\section{Author:}

Mikhail E. Stepantsov, Ph.D., Senior Researcher at Keldysh Institute of Applied Mathematics (4, Miusskaya Sq., Moscow, Russia) 


\section{Модель информационной войны, основанная на клеточном автомате* М.Е. Степанцов **}

Институт прикладной математики им. М.В. Келдыша РАН, Москва, Российская Федерация

В работе рассматривается интегро-дифференциальная модель информационного противостояния, основанная на нейрологической схеме Рашевского. Данную модель трудно модифицировать для решения задач, в которых необходимо учитывать различия восприятия пропаганды индивидуумами, особое влияния референтных групп на человека или различие индивидуальных характеристик людей. Этого можно достичь при помощи дискретной модели, основанной на клеточном автомате и имеющей макродинамику, согласующуюся с макродинамикой непрерывной модели. Такая модель предлагается в данной работе. Ее динамика была исследована и было показано, что с ее помощью можно повторить основные результаты. Полученные при помощи непрерывной модели.

Keywords: информационная война, математическое моделирование, клеточные автоматы, имитационное моделирование.

\section{Aвтор:}

Степанцов Михаил Евгеньевич, кандидат физико-математических наук, старший научный сотрудник Института прикладной математики им. М.В. Келдыша РАН (Россия, Москва, Миусская пл., 4)

\footnotetext{
* Исследование выполнено при финансовой поддержке РФФИ в рамках проектов № 18-01-00619, 18-01-00551 и 19-010-00423.

** E-mail: mews@yandex.ru.
} 